\title{
Kajian Teoritis Pengembangan Bahan Ajar Bahasa Arab
}

\author{
Muhammad Syaifullah \\ Institut Agama Islam Ma'arif NU (IAIM NU) Metro Lampung \\ muhammadsyaifullah121285@gmail.com \\ Nailul Izzah \\ Institut Agama Islam Ma'arif NU (IAIM NU) Metro Lampung \\ saygheza13@gmail.com
}

\begin{abstract}
The need for Arabic language teaching materials is very important in achieving learning objectives. A teacher, student and material is an inseparable unit for success in a learning process. The purpose of what and how the position of teaching materials in learning; includes the role for teachers, students, in classical, individual, and group learning. Principles for the development of Arabic teaching materials; Principles of Socio-Culture, Psychological Principles, and Principles of Language and Education. Then how about the character and steps of developing Arabic teaching materials. Type of library research or library research, which takes data sources from theories in literature. The implications of this study have contributed to the ease of a teacher to develop teaching materials that will be applied to students by paying attention to the principles and characters of the teaching material, namely Arabic.
\end{abstract}

Keywords: development, teaching materials, Arabic

\begin{abstract}
Abstrak
Kebutuhan terhadap bahan ajar bahasa Arab sangatlah penting dalam ketercapaian tujuan pembelajaran. Seorang guru, siswa dan materi merupakan satu kesatuan yang tidak dapat dipisahkan untuk keberhasilan dalam sebuah proses pembelajaran tersebut. Penelitian ini bertujuan untuk mengetahui tentang apa dan bagaimana kedudukan bahan ajar dalam pembelajaran; peran guru dan siswa, dalam pembelajaran klasikal, individual, maupun berkelompok. Kemudian asas-asas pengembangan bahan ajar bahasa Arab; Asas Sosial-Budaya, Asas Psikologis, dan Asas Kebahasaan dan Pendidikan. Kemudian bagaimana karakter dan langkah-langkah mengembangkan bahan ajar bahasa Arab. Jenis penelitian pustaka atau library research, yang mengambil sumber data dari teori-teori
\end{abstract}


secara kepustakaan. Implikasi kajian ini memiliki kontribusi terhadap kemudahan seorang guru untuk mengembangkan bahan ajar yang akan diterapkan kepada siswanya dengan memperhatikan asas-asas dan karakter dari bahan ajar tersebut yaitu bahasa Arab.

Kata Kunci: pengembangan, bahan ajar, bahasa arab

\section{Pendahuluan}

Perkembangan dan perubahan yang terjadi dalam kehidupan bermasyarakat berbangsa dan bernegara di Indonesia tidak terlepas pengaruh perubahan global, perkembangan ilmu pengetahuan dan teknologi, serta seni dan budaya. Perubahan secara terus menerus ini menuntut perlunya perbaikan sistem pendidikan nasional, termasuk penyempurnaan kurikulum sehingga dapat mewujudkan masyarakat yang mampu bersaing dan menyesuaikan diri dengan perubahan zaman. ${ }^{1}$

Sampai saat ini, pembelajaran bahasa Arab di Indonesia sepertinya belum menunjukkan hasil yang memuaskan. Hal ini bisa disebabkan karena beberapa faktor, misalnya: Kurikulum, pengajar, bahan ajar dan lain sebagainya. Dari aspek kurikulum, masalah yang kerap terjadi adalah karena kurikulum yang digunakan belum merepresentasikan aspek-aspek yang dibutuhkan siswa secara komprehensif. Dari aspek pendidik adalah karena kurang siapnya pendidik, baik dari aspek teori maupun praktik mengajarnya. Dari aspek bahan ajar adalah karena adanya ketidaksesuaian antara tujuan pembelajaran dan materi yang diajarkan sehinggga hasilnya kurang efektif.

Selain itu, bahasa ajar bahasa Arab yang ada di Indonesia kurang berkembang, tidak seperti bahasa asing yang lain seperti bahasa Inggris, bahkan masih banyak madrasah yang menggunakan bahan ajar bahasa Arab dari Timur Tengah. Di sisi lain, inovasi dan pengembangan bahan ajar bahasa Arab telah menjadi keniscayaan seiring dengan derasnya arus perkembangan ilmu pengetahuan dan teknologi. Oleh karena itu, kompetensi untuk mengembangkan bahan ajar harus benar-benar dikuasi oleh para pengajar bahasa Arab.

Bagi siswa dalam mempelajari materi pelajaran bahasa Arab masih merasakan kesulitan. Hal tersebut dikarenakan dalam pembelajaran bahasa Arab,

\footnotetext{
${ }^{1}$ Muhammad Syaifullah, Pembelajaran Kooperatif Tipe Make A Match Dalam Meningkatkan Penguasaan Kosa Kata Bahasa Arab Santri TPA Al-Barokah Hadimulyo Timur Metro Pusat, Jurnal AtTa'dib, Vol 11, No.2, 2016/DOI:http://dx.doi.org/10.21111/at-tadib.v1 1i2.781.
} 
seringkali siswa dihadapkan problematika yang sulit, mengingat bahasa Arab bukan bahasa ibu bagi peserta didik. "Problematika tersebut meliputi problematika linguistik, seperti tata bunyi, kosa kata, tata kalimat dan tulisan, maupunproblematika non linguistik, sepertimenyangkutsegisosio-budaya."

Fakta dilapangan menyatakan, bahwa terdapat beberapa kesulitankesulitan mahasiswa dalam memahami materi yang diajarakan oleh dosen.

1. Dari bahan ajar. Penulis mendapatkan bahwa bahan ajar yang masih banyak digunakan oleh seorang dosen dalam pembelajaran bahasa Arab dengan menggunakan bahan ajar kitab "baina yadaik", yang mana pada hakikatnya tidak terdapat hubungan yang siknifikan dari teori yang diajarkan dengan beberapa faktor segi sosio-budaya bagi pelajar di Indonesia.

2. Dari metode dan cara yang digunakan oleh seorang dosen dalam memberi pembelajaran kepada mahasiswa masih menggunakan metodepembelajarantradisional, sehingga proses pembelajaran yang cenderung pada ketidak pencapaian target materi kurikulum.

Dari latar belakang masalah, dapat diidentifikasi permasalahan yang muncul yaitu belajar bahasa Arab sangat memerlukan usaha dan motivasi yang kuat baik secara internal maupun eksternal. Keberhasilan studi ini tidak sematamata atas ketepatan dan peran dari media yang dipakai tetapi juga tergantung pada usaha-usaha yang dilakukan oleh mahasiswa dalam menindaklanjuti dan mengembangkan ilmu yang telah mereka terima.

Berdasarkan identifikasi masalah di atas, penulis berupaya mengadakan penelitian dalam suatu kajian teoritis dalam pengembangan bahan ajar bahasa Arab yang dapat dilakukan oleh seorang guru atau dosen, sehingga dapat tercapai target materi dari kurukulum dan ketercapaian tujuan pembelajaran.

\section{Pembahasan dan Hasil}

\section{A. Pengertian dan Kedudukan Bahan Ajar Dalam Pembelajaran}

Ada banyak term tentang bahan Bahan ajar yang dikemukan oleh praktisi maupun ahli pendidikan, namun pada prinsipnya sama bahwa bahan ajar merupakan bahan-bahan atau materi pelajaran yang disusun secara lengkap dan sistematis berdasarkan prinsip-prinsip pembelajaran yang digunakan guru dan siswa dalam proses pembelajaran. Bahan ajar bersifat sistematis artinya disusun

${ }^{2}$ Muhammad Syaifullah, Pembelajaran Metode Kooperatif Tipe Jigsaw Dalam Meningkatkan Hasil Belajar Bahasa Arab (Qowa'id) Mahasiswa Perbankan Syari'ah LAIM NU Metro Lampung Tabun 2017, Jurnal Bahasa Lingua Scientia, Vol 9, No.2, 2017/DOI:http://doi.org/10.21274/1s.2017.9.2.177-208 
secara urut sehingga memudahkan siswa belajar. Di samping itu, bahan ajar juga bersifat unik dan spesifik. Unik maksudnya bahan ajar hanya digunakan untuk sasaran tertentu dan dalam proses pembelajaran tertentu, dan spesifik artinya isi bahan ajar dirancang sedemikian rupa hanya untuk mencapai kompetensi tertentu dari sasaran tertentu. ${ }^{3}$

Bahan ajar dapat berupa segala bentuk bahan yang digunakan untuk membantu guru atau instruktur dalam melaksanakan proses pembelajaran di kelas. Bahan yang dimaksud bisa berupa bahan tertulis maupun tidak tertulis. ${ }^{4}$ Sementara menurut Widodobahan ajar adalah seperangkat sarana yang berisikan materi pembelajaran, metode, batasan-batasan, dan cara mengevaluasi yang didesain secara sistematis dan menarik dalam rangka mencapai tujuan yang diharapkan, yaitu mencapai kompetensi dan subkompetensi dengan segala kompleksitasnya. ${ }^{5}$

Majid mengungkapkan bahwa bahan ajar adalah segala bentuk bahan yang digunakan untuk membantu guru/instruktur dalam melaksanakan kegiatan belajar mengajar. Bahan yang dimaksud bisa berupa bahan ajar tertulis maupun bahan ajar tidak tertulis. Dengan bahan ajar memungkinkan siswa dapat mempelajari suatu kompetensi atau kompetensi dasar secara runtut dan sistematis sehingga secara akumulatif mampu menguasai semua kompetensi secara utuh dan terpadu. ${ }^{6}$

Menurut Joni, bahan ajar mempunyai fungsi yang sangat penting dalamkegiatan pembelajaran, seperti:memberikan petunjuk yang jelas bagipembelajar dalam mengelola kegiatan belajar mengajar, menyediakanbahan/alat yang lengkap yang diperlukan untuk setiap kegiatan, merupakanmedia penghubung antara pembelajar dan pebelajar, dapat dipakai olehpebelajar sendiri dalam mencapai tujuan yang diharapkan, serta dapatdigunakanuntuk program perbaikan. ${ }^{7}$

hlm. 1.3

${ }^{3}$ Tian Belawati, et.al, Pengembangan Bahan Ajar, (Jakarta: Pusat Penerbitan UT, 2003),

${ }^{4}$ Andi Prastowo, Panduan Kreatif Membuat Baban Ajar Inovatif: Menciptakan Metode Pembelajaran yang Menarik dan Menyenangkan, (Yogyakarta: Diva Press, 2012), cet. IV, hlm. 16

${ }^{5}$ Chomsin S. Widodo dan Jasmadi, Panduan Menyusun Bahan Ajar Berbasis Kompetensi, (Jakarta: Gramedia, 2008), hlm. 40

${ }^{6}$ Abdul Majid, Perencanaan Pembelajaran: Mengembangkan Standar Kompetensi Guru, (Bandung: Remaja Rosdakarya, 2008), cet. 5, hlm. 173.

${ }^{7}$ R.T. Joni, Pengembangan Paket Belajar,(Jakarta: Depdikbud. P2LPTK, 1984), hlm. 4 
Lebih dari itu, Belawati menjelaskan bahwa peran bahan ajar sangat penting, peran guru dan siswa, baik dalam pembelajaran klasikal, individual, maupun kelompok. ${ }^{8}$ Agar diperoleh pemahaman yang lebih jelas akan dijelaskan masing-masing peran sebagai berikut:

1. Bagi guru, bahan ajar bagi guru memiliki peran, yaitu:

a. Menghemat waktu guru dalam mengajar

Adanya bahan ajar, siswa dapat ditugasi mempelajari terlebih dahulu topik atau materi yang akan dipelajarinya, sehingga guru tidak perlu menjelaskan secara rinci lagi.

b. Mengubah peran guru dari seorang pengajar menjadi seorang fasilitator. Adanya bahan ajar dalam kegiatan pembelajaran maka guru lebih bersifat memfasilitasi siswa dari pada penyampai materi pelajaran.

c. Meningkatkan proses pembelajaran menjadi lebih efektif dan interaktif. Adanya bahan ajar maka pembelajaran akan lebih efektif karena guru memiliki banyak waktu untuk membimbing siswanya dalam memahami suatu topik pembelajaran, dan juga metode yang digunakannya lebih variatif dan interaktif karena guru tidak cenderung berceramah.

2. Bagi siswa, bahan ajar bagi siswa memiliki peran, yakni:

a. Siswa dapat belajar tanpa kehadiran/harus ada guru

b. Siswa dapat belajar kapan saja dan dimana saja dikehendaki

c. Siswa dapat belajar sesuai dengan kecepatan sendiri.

d. Siswa dapat belajar menurut urutan yang dipilihnya sendiri.

e. Membantu potensi untuk menjadi pelajar mandiri.

3. Dalam Pembelajaran Klasikal, bahan ajar memiliki peran, yakni:

a. Dapat dijadikan sebagai bahan yang tak terpisahkan dari buku utama.

b. Dapat dijadikan pelengkap/suplemen buku utama.

c. Dapat digunakan untuk meningkatkan motivasi belajar siswa.

d. Dapat dijadikan sebagai bahan yang mengandung penjelasan tentang bagaimana mencari penerapan, hubungan, serta keterkaitan antara satu topik dengan topik lainnya.

4. Dalam Pembelajaran Individual, bahan ajar memiliki peran, yakni:

a. Sebagai media utama dalam proses pembelajaran

b. Alat yang digunakan untuk menyusun dan mengawasi proses siswa memperoleh informasi.

c. Penunjang media pembelajaran individual lainnya.

5. Dalam Pembelajaran Kelompok, bahan ajar memiliki peran, yakni:

a. Sebagai bahan terintegrasi dengan proses belajar kelompok.

b. Sebagai bahan pendukung bahan belajar utama.?

${ }^{8}$ Tian Belawati, Pengembangan, hlm. 14-19

${ }^{9}$ Khairi Abu Syairi, "Pengembangan Bahan Ajar Bahasa Arab", Jurnal Dinamika Ilmu IAIN Samarinda, Vol. 13, No. 55 


\section{B. Asas-asas dalam pengembangan bahan ajar bahasa Arab}

Dalam menyusun dan mengembangkan bahan ajar bahasa Arab, terdapat beberapa hal yang harus diperhatikan sebagai landasan atau asasasasnya, dengan tujuan agar bahan ajar yang dihasilkan bersifat kontekstual dan tepat kebutuhan siswa.Al-Ghali dan Abdullah merinci asas-asas dalam penyusunan dan pengembangan bahan ajar sebagaimana berikut: ${ }^{10}$

\section{Asas Sosial-Budaya}

Ketika kita akan membicarakan aspek sosial-budaya sebagai salah satu asas pembuatan bahan ajar bahasa Arab, maka poin-poin penting sebagai pokok bahasannya meliputi: pengertian kebudayaan secara umum dan kebudayaan Islam secara khusus, karakteristik kebudayaan, dan hubungan kebudayaan dengan pengembangan bahan ajar.

Seseorang yang mempelajari bahasa asing tertentu tidak akan dapat memahaminya dengan baik tanpa memahami kebudayaan masyarakatnya. Bahasa Arab misalnya, seseorang yang mempelajari bahasa Arab tanpa memahami kebudayaan Arab dan kebudayaan islam, maka dia tidak dapat memahaminya dengan sempurna, karena itu ada ungkapan bahwa "al-lugahwi'a al-tsaqafah" (bahasa adalah bejana kebudayaan).

\section{Asas Psikologis}

Pengembangan bahan ajar bahasa Arab harus memperhatikan aspekaspek psikologis siswa sehingga dapat meningkatkan motivasi belajar siswa. Halhal psikologis yang harus diperhatikan dalam pengembangan bahan ajar bahasa Arab adalah sebagai berikut:

a. Bahan ajar hendaknya sesuai dengan kemampuan intelektual siswa

b. Memperhatikan perbedaan individual antar siswa,

c. Mampu merangsang daya pikir siswa sehingga dapat membantu proses pembelajaran dan pemerolehan bahasa Arab,

d. Tingkat persiapan dan kemampuan berbahasa Arab siswa harus disesuaikan dengan materi,

e. Tingkat usia siswa, setiap bahan ajar diperuntukkan untuk usia berapa, karena setiap usia tertentu memerlukan perlakuan yang berbeda,

f. Dalam menggunakan bahasa Arab secara alami, materi harus dapat memotivasi siswa,

g. Saling berkesinambungan antara buku siswa dan buku pegangan guru

${ }_{10}$ Nashir Abdullah Al Ghali dan Abdul Hamid Abdullah, Usus I'dad Al Kutub AlTa'liimiyyat li Ghairi Al Naatbiquin bihaa. (Riyadh: Dar Al Gha, 1991), hlm. 19 
h. Bahan ajar bahasa Arab mampu menciptakan orientasi dan norma-norma yang diharapkan oleh mahasiswa

Yunus melakukan sebuah penelitian mengenai tujuan-tujuan yang dapat mendorong dan memotivasi pembelajar untuk belajar bahasa Arab sebagai bahasa kedua yaitu sebagai berikut ${ }^{11}$;

a. Membaca Al-Qur'an dan Hadits;

b. Membaca ilmu-ilmu keislaman (fikih, tafsir, sejarah, dll);

c. Komparasi Islam dengan agama lain;

d. Melancong ke negara-negara Arab;

e. Bekerja di negara-negara Arab di berbagai bidang dan profesi;

f. Mendirikan pabrik atau perusahaan di negara-negera Arab; dan

g. Bekerja di kedutaan-kedutaan besar di negera Arab.

\section{Asas Kebahasaan dan Pendidikan}

Asas kebahasaan yang dimaksud adalah memperhatikan bahasa yang akan diajarkan kepada siswa meliputi unsur-unsur dan keterampilan bahasa, sehingga materi yang disajikan sesuai dengan tujuan-tujuan yang telah ditetapkan.

Sedangkan asas pendidikan adalah hal-hal yang terkait dengan teori pendidikan dalam pengembangan bahan ajar, seperti materi dimulai dari yang mudah kepada yang lebih kompleks, dari yang konkrit ke yang abstrak, dari detail ke suatu yang konsep, atau sebaliknya dari suatu konsep ke pemerinciannya, sesuai dengan prinsip-prinsip pendidikan dalam pengembangan bahan ajar.

\section{Karakteristik Bahan Ajar Bahasa Arab}

Setidaknya ada tiga komponen utama bahan ajar yang menjadi karakteristik bahan ajar, termasuk dalam hal ini bahan ajar bahasa Arab, yaitu: komponen utama, pelengkap, dan evaluasi hasil belajar. ${ }^{12}$ Komponen utama mencakup informasi atau topik utama yang ingin disampaikan kepada siswa, atau yang harus dikuasai siswa, komponen pelengkap mencakup informasi atau topik tambahan yang terintegrasi dengan bahan ajar utama, atau topik pengayaan wawasan siswa, seperti materi pengayaan, bacaan tambahan, jadwal, silabus dan bahan pendukung non cetak lainnya, dan komponen evaluasi hasil belajar

${ }^{11}$ Fathi Yunus., dkk, Ta'lim al-Lughah al-'Arabiyah, (Cairo: Dar al-Nahdah, 1984), hlm.

12 P. Pannen, Mengajar di Perguruan Tinggi: Pengembangan Baban Ajar, Jakarta: PAUPPAI, Universitas Terbuka, 1996), hlm. 13 
mencakup tes dan non tes yang dapat digunakan untuk tes formatif dan sumatif siswa selama proses pembelajaran.

Supaya bahan belajar dapat memudahkan pembelajaran, maka setiap bahan ajar harus memenuhi komponen-komponen yang relevan dengan kebutuhan siswa. Komponen-komponen tersebut juga harus dapat memberikan motivasi, mudah dipelajari dan dipahami siswa. Lebih penting lagi adalah relevan dengan sifat mata pelajaran yang disajikan. Selain itu, bahan ajar juga harus memiliki karakteristik tertentu yang membedakannya dengan buku-buku yang.

Agar memudah dan memotivasi siswa dalam mempelajari dan memahami isi bahan ajar, maka dalam bahan ajar itu harus tersedia:

a. Petunjuk yang mampu menyajikan langkah-langkah yang mudah untuk memahami dan mengikuti setiap proses pembelajaran sesuai dengan materi yang disajikan;

b. Setiap materi yang disajikan harus terlebih dahulu dijelaskan tujuan pembelajaran yang ingin dicapai, dengan maksud untuk mengetahui tingkat pencapaian siswa terhadap materi yang dipelajari;

c. Untuk menunjang penyajian materi perlu disajikan map atau bisa juga kerangka isi dalam bentuk diagram agar mahasiswa dapat mengetahui dan memahami bagian-bagian yang mencakup pokok bahasan dan sekaligus dapat melihat hubungan masing-masing bagian dalam pokok bahasan tersebut;

d. Penyajian materi dari pokok bahasan sampai ke sub pokok bahasan diuraikan pada bagian ini secara jelas dan dibantu dengan gambar/ilustrasi.

e. Rangkuman,

f. Evaluasi formatif, dan tindak lanjut untuk kegiatan belajar berikutnya,

g. Daftar bacaan, dan

h. Kunci jawaban.

Sehingga, secara garis besar bahan ajar bahasa Arab yang baik setidaknya terdiri dari: 1) buku siswa; 2) buku guru; dan 3) sejumlah komponen yang meliputi: buku kerja atau buku kegiatan, materi bacaan tambahan, buku tes, kaset untuk mendengarkan, kaset untuk pelafalan, materi latihan tata bahasa dan kamus kosa kata, juga ditambahkan materi berbentuk video.

\section{Analisis Bahan Ajar Bahasa Arab}

\section{Gambaran Umum Tentang Buku Al-Arabiyah Baina Yadaik}

Buku ajar merupakan salah satu bentuk dari bahan ajar, buku ajar mempunyai peran penting dalam menunhang proses pembelajaran. Bahan ajar merupakan informasi, alat dan teks yang diperukan guru untuk perencanaan dan penelaahan implementasi pembelajaran. Bahan ajar adalah segala bentuk bahan 
yang digunakan untuk membantu guru dalam melaksanakan kegiatan belajar mengajar di kelas.

Kitab Al Arabiyah baina Yadaik adalah sebuah buku pembelajaran bahasa arab yang paling modern. Kitab ini disusun dengan sistematika pembelajaran yang terbaik sehingga memudahkan setiap orang untuk mempelajari dan memahami bahasa arab. Berikut ini akan digambarkan sekilas tentang buku tersebut.

Buku ajar ini berjudul Al Arabiyah baina Yadaik : Silsilatun Fi Ta'lim alLugoh al-Arabiyah Li Goiri an-Natiqin Biha (seri pembelajaran bahasa arab untuk penutur asing) di tulis oleh Dr Abdurrahman bin Ibrohim al-Fauzan, Ustadz Mukhtar al-Thahir Husein dan Ustad Muhammad Abdul Khaliq, ketiganya dosen di Ma'had al-Lugoh al-Arabiyah (Institut Bahasa Arab) King Saud University Riyadh Saudi Arabia.

Buku ini diterbitkan oleh Mu'assasah al-Waqaf al-Islami Riyadh. Tujuan penulisan buku seri pembelajaran bahasa arab ini adalah untuk mengantarkan peserta didik memiliki kemampuan berbahasa (kifayah al-lugowiyah), kemampuan berkomunikasi (kifayah ittisholiyyah), kemampuan berbudaya (kifayah tsaqofiyah).

Kifayah Lugowiyah mencakup dua hal yaitu keterampilan bahasa (istima', kalam, qiroah, kitabah) dan tiga unsur bahasa yaitu al-aswat (bunyi), al-mufradat (perbendaharaan kata), dan al-tarakib (struktur kalimat). Kifayah ittisholiyyah dimaksudkan sebagai kemampuan peserta didik dalam komunikasi langsung, baik lisan maupun tulisan, dengan pemilik bahasa dalam konteks pergaulan sosial mereka. Sedangkan kifayah tsaqofiyyah dimaksudkan sebagai kemampuan peserta didik dalam memahami ragam aspek budaya bahasa, yakni budaya bahasa Arab dan Islam.

Evaluasi yang dapat penulis analisis dari segi al-mufradat (perbendaharaan kata);

a. Terdapat latihan atau tadribat mufrodat baru pada setiap pelajaran dalam buku arabiyah baiana yadaiknamun tidak teratur.

b. Menurut penulismufrodat yang terdapat di dalam buku arabiyah baiana yadaik disajikan secara langsung atau tidak bertahap. Hal ini terlihat dari mufradat yang digabungkan dalam satu pelajaran untuk dua topik pembahasan.

c. Menurut penulis tidak terdapat penguatan terhadap mufrodat sebelumya yang terdapat di dalam buku arabiyah baina yadaik.

d. Pengembangan mufrodat baru di dalam pengetahuan struktur kalimat terdapat pada qowaid lughoh. 
e. Pengenalan mufrodat baru di dalam buku Arabiyah Baina Yadaik tidak menggunakan media.

f. Mufrodat yang terdapat dalam materi buku Arobiyah Baina Yadaik masih dianggap sulit, karena tidak berhubungan dengan asas-asas mahasiswa di Indonesia.

Oleh karena itu, seorang guru atau dosen bahasa Arab dalam menyusun dan mengembangkan bahan ajar bahasa Arab, terdapat beberapa hal yang harus diperhatikan sebagai landasan atau asas-asasnya, dengan tujuan agar bahan ajar yang dihasilkan bersifat kontekstual dan tepat kebutuhan siswa. Adapun strategi pemilihan dan penyusunan untuk mengembangkan bahan ajar bahasa Arab diuraikan sebagai berikut.

\section{Strategi Pemilihan dan Penyusunan Dalam Pengembangan Bahan Ajar Bahasa Arab}

Agar mencapai pembelajaran yang efektif dan efisien serta sampai pada tujuan, pengembangan atau revisi secara berkala tentu menjadi hal yangsangat penting. Dick dan Carey mengemukakan ada dua pengembanganatau revisi yang perlu dipertimbangkan untuk mencapai hal di atas, yaitu: (1)revisi terhadap isi atau subtansi bahan pembelajaran agar lebih cermat, (2)revisi terhadap cara-cara yang dipakai dalam menggunakan bahanpembelajaran. ${ }^{13}$

Dalam mengembangkan bahan ajar, ada beberapa faktor yang perlu dipertimbangkan, yaitu: ${ }^{14}$

a. Isi bahan ajar

Isi bahan ajar berhubungan dengan validitas atau kebenaran isi secara keilmuan dan berkaitan dengan keselarasan isi atau kebenaran isi berdasarkan sistem nilai yang dianut oleh masyarakat atau bangsa. Terkait dengan validitas isi, maka isi bahan ajar bahasa Arab yang dikembangkan seyogyanya berdasarkan konsep dan teori pembelajaran bahasa Arab, perkembangan mutakhir, dan hasil penelitian empiris yang dilakukan dalam bidang ilmu bahasa Arab. Adapun dalam keselarasan isi, maka isi bahan ajar bahasa Arab disesuaikan dengan sistem nilai dan falsafah hidup yang berlaku dalam negara dan masyarakat di lingkungan tempat sekolah berada.

${ }^{13}$ Hamzah B. Umo, Model Pembelajaran-Menciptakan Proses Belajar Mengajar yang Kreatif dan Efektif, (Jakarta: Bumi Aksara, 2007), hlm. 98-99

${ }^{14}$ Abdul Hamid, dkk. Pembelajaran Bahasa Arab: Pendekatan, Metode, Strategi, Materi, dan Media, (Malang: UIN-Malang Press, 2008), hlm. 102-110 
b. Ketepatan cakupan isi

Hal ini berkaitan dengan isi bahan ajar dari sisi keluasan dan kedalaman isi atau materi, serta keutuhan konsep berdasarkan bidang ilmu bahasa Arab. Kedalaman dan keluasan isi bahan ajar sangat menentukan kadar bahan ajar yang akan dikembangkan bagi siswa sesuai dengan kemampuan dan tingkat pendidikan yang sedang ditempuh. Adapun acuanacuan utama dalam penentuan kedalaman dan keluasan isi bahan ajar adalah kurikulum (termasuk silabus).

c. Ketercernaan materi

Hal ini berkaitan dengan kemudahan bahan ajar tersebut dipahami dan dimengerti oleh siswa sebagai pengguna, meliputi: pemaparan yang logis, penyajian materi yang runtut, ada contoh dan ilustrasi, alat bantu yang memudahkan, format yang tertib dan konsisten, dan penjelasan tentang relevansi dan manfaat bahan ajar.

d. Penggunaan bahasa

Penggunaan bahasa dalam pengembangan bahan ajar berkaitan dengan pemilihan ragam bahasa, pemilihan kata, penggunaan kalimat efektif, dan penyusunan paragraf yang bermakna.

e. Perwajahan atau pengemasan

Berhubungan dengan penataan letak informasi dalam satu halaman cetak dan pengemasan dalam paket bahan ajar multimedia.

f. Ilustrasi

Ilustrasi dimanfaatkan untuk menarik, memotivasi, komukatif,membantu retensi dan pemahaman siswa terhadap isi pesan, bisa berupatabel, diagram, kartu, skema, foto, dan sebagainya.

g. Kelengkapan komponen

Berkaitan dengan paket bahan ajar yang dapat berfungsi sebagai komponen utama, komponen pelengkap, dan komponen evaluasi hasil belajar.

\section{Langkah-langkah Penyusunan Dalam Pengembangan Bahan Ajar Bahasa Arab}

Langkah-langkah pengembangan bahan ajar sangat beragam. Di antaranya adalah langkah-langkah pengembangan bahan ajar menurut model Dick dan Carey, yang meliputi:mengidentifikasi tujuan pembelajaran, melakukan analisis pembelajaran,mengidentifikasi perilaku awal/garis entry behavior, 
merumuskan tujuan pembelajaran, mengembangkan butir tes, mengembangkan strategi pembelajaran, mengembangkan isi program pembelajaran, merancang dan melaksanakan evaluasi, dan merevisi paket pembelajaran.

a. Identifikasi tujuan pembelajaran, dilakukan dengan memperhatikan dan mengadakan penilaian terhadap kebutuhan siswa, melalui analisis kebutuhan (need assesment) peserta didik sesuai dengan tuntutan kurikulum.

b. Analisis pembelajaran, dilakukan dengan cara: mengklasifikasikan rumusan tujuan menurut jenis ranah belajar (keterampilan psikomotor, keterampilan intelektual, informasi verbal, sikap), danmengenali teknik analisis pembelajaran yang cocok untuk memeriksa secara tepat perbuatan belajar yang sebaiknya dilakukan dalam mencapai tujuan sesuai dengan karakteristik mata pelajaran yang menjadi objek penelitian, tujuan difokuskan pada pencapaian keterampilan bahasa.

c. Identifikasi perilaku awal, dilakukan dengan memberikan pretest kepada sampel penelitian.

d. Perumusan TIK, dilakukan dengan menjabarkan setiap tujuan umum mata pelajaran dalam bentuk perilaku atau kompetensi yang harus dicapai oleh mahasiswa setelah selesai mengikuti setiap unit pembelajaran.

e. Menyusun butir-butir tes, untuk mengukur kemampuan peserta didik dalam mencapai apa yang telah dicantumkan dalam tujuan, sebagai proses dalam pengumpulan data dan informasi yang dapat dipergunakan untuk merevisi pembelajaran. Dalam pengembangan ini, pengukuran dilakukan melalui tes teori tertulis, mengingat tujuan khusus pembelajaran yang ingin dicapai sebagian besar termasuk ranah kognitif. Di samping tes teori tertulis, juga dikembangkan tes praktik untuk mengukur keterampilanpsikomotorik siswa.

f. Mengembangkan strategi pembelajaran, yang mendeskripsikan komponenkomponen umum dari suatu perangkat isi pelajaran yang akan dipergunakan untuk memperjelas isi pelajaran. Pengembangan strategi pembelajaran mencakup: kegiatan pengajaran, penyajian informasi, partisipasi mahasiswa, pertanyaan mahasiswa.

g. Mengembangkan bahan ajar, mengacu pada tujuan khusus pembelajaran, dan strategi pembelajaran. Bahan ajar yang dikembangkan berbentuk: buku panduan guru sebagai penuntun penggunaan bahan ajar, dan bahan ajar siswa, sebagai sumber dalam proses belajar mandiri siswa dan dalam tutorial. Dalam pengembangan bahan ajar ini, dilakukan evaluasi oleh ahli bidang studi, ahli perancang, dan ahli media.

h. Evaluasi untuk mengukur tingkat keefektifan, efisiensi, dan daya tarik strategi pembelajaran berdasarkan masukan, tanggapan, saran, komentar dan penilaian ahli. Hasil evaluasi para ahli ini kemudian diguna untuk keperluan revisi atau penyempurnaan kualitas produk bahan ajar hasil pengembangan. Dalam pengembangan ini, evaluasi yang dilakukan adalah: evaluasi oleh para 
ahli, dan teman sejawat, evaluasi perorangan,evaluasi kelompok kecil, dan uji coba lapangan terbatas.

i. Revisi produk berdasarkan data yang diperoleh dari kegiatan evaluasi.

Selanjutnya data tersebut diikhtisarkan dan ditafsirkan sebagai usaha untuk mengenali kesulitan-kesulitan dan kekurangan yang terdapat pada bahan ajar. Pada dasarnya ada dua jenis revisi pembelajaran yang perlu diperhitungkan: revisi terhadap substansi seluruh komponen, dan revisi terhadap cara-cara atau prosedur dalam menggunakan bahan ajar (Dick dan Carey, 1990). Dalam pengembangan ini, revisi produk pengembangan paket pembelajaran dilakukan pada setiap komponen bahan ajar, yaitu: petunjuk, tujuan khusus pembelajaran, isi bahan pembelajaran, gambar, rangkuman, evaluasi formatif, dan daftar bacaan. Hasil revisi produk berbentuk bahan ajar yang siap pakai.

Adapun penjelasan dalam pengembangan bahan ajar bahasa Arab seperti berikut ini: ${ }^{15}$

a. Analisis

Pada tahap analisis ini, yang dilakukan adalah mengumpulkan informasi berkaitan dengan mata pelajaran yang akan dikembangkan dan silabusnya, juga mengumpulkan informasi tentang karakteristik awal siswa.

Sebelum memulai proses pengembangan, tahap pertama yang dilakukan adalah menentukan materi apa yang akan dikembangkan. Setelah ditetapkan, kemudian menganalisis silabus untuk diidentifikasi pokok-pokok bahasannya, dan mengenali karakteristik siswa sebagai pengguna buku bahan ajar bahasa Arab yang akan dikembangkan. Mengidentifikasi tingkah laku dan karakteristik siswa adalah penting sekali untuk dipertimbangkan dalam rangka merancang kegiatan-kegiatan pembelajaran.

Beberapa hal yang perlu diidentifikasi, khususnya yang berkaitan dengan siswa sebagai pengguna buku bahan ajar bahasa arab adalah:

1) Kondisi dimana sumber belajar berupa buku ajarditerapkan,

2) Siapa yang menggunakan buku ajar, dan

3) Untuk kelas atau tingkat berapa buku ajar itu digunakan.

b. Perancangan

Pada tahap ini, langkah-langkah yang harus ditempuh adalah:

1) Menganalisis dan merumuskan tujuan pembelajaran 
Dengan melibatkan empat unsur, yaitu: $\mathrm{A}=$ Audience, artinya siapa yang akan belajar. $\mathrm{B}=$ Behavior, artinya perilaku khusus yang akan dimunculkan oleh siswa setelah selesai proses belajar mengajar. $\mathrm{C}=$ Condition, artinya keadaan yang harus dipenuhi pada saat proses belajar-mengajar berlangsung dan atau keadaan atau alat yang digunakan siswa pada saat ia di tes, bukan pada saat ia belajar. $\mathrm{D}=$ Degree, artinya tingkat keberhasilan yang harus dipenuhi oleh siswa.

2) Mengembangkan butir-butir tes

Penyusunan butir-butir tes perlu memperhatikan hal-hal sebagai berikut:

a) Berdasarkan kriteria yang dirumuskan dalam tujuan khusus pembelajaran atau indicator keberhasilan,

b) Berdasarkan muatan materi pada pokok bahasan yang akan dikembangkan dalam penyusunan pertanyaan,

c) Memperhatikan kesesuaian butir soal dengan tujuan khusus pembelajaran atau indikator keberhasilan,

d) Membuat bentuk-bentuk soal dan menyusunnya

e) Menulis petunjuk, dan

f) Mengerjakan soal-soal yang menghasilkan kunci jawaban.

Hasil akhir dari langkah ini adalah seperangkat soal-soal latihan dan soal-soal tes yang dapat digunakan untuk mengukur penguasaan siswa terhadap materi yang sudah dipelajarinya. Di dalam pembelajaran selanjutnya butir-butir soal ini akan dikembangkan menjadi soal-soal latihan, tugas-tugas, soal-soal tes sumatif atau formatif

3) Mengembangkan strategi pembelajaran

Dalam strategi pembelajaran, terdapat lima komponen utama yang akan menjadi fokus, yaitu:Kegiatan pembelajaran,penyajian atau penyampaian informasi, peran serta siswa, pengetesan, dan tindak lanjut.

Untuk meningkatkan efektivitas penggunaannya, buku ajar disusun dengan dilengkapi beberapa komponen pendukung pembelajaran, yaitu: petunjuk cara mempelajari uraian pada setiap isi topik, tujuan pembelajaran setiap topikdan sub topik, daftar bacaan yang relevan, dan soal-soal latihan.

4) Mengembangkan media pembelajaran

Media dan sumber belajar menurut Belawati adalahalat dan cara untuk memfasilitasi, mempermudah proses belajar siswa,serta membuat proses belajar menjadi lebih menyenangkan danmenarik bagi siswa.Media dan sumber belajar yang dapat dipilih untuk paket bahanajar pembelajaran 
bahasa arab antara lain: bitaqah al-mufrodat almushawaroh,poster, kaset, CD, VCD, dll.

5) Mengembangkan materi pembelajaran

Materi pembelajaran dikembangkan dalam bentuk buku ajar yang dilakukan dengan beberapa langkah sebagai berikut:

a) Memilih dan mengumpulkan materi pembelajaran yang ada dan relevan untuk digunakan,

b) Menyusun materi sesuai dengan urutan kegiatan pembelajaran,

c) Mengidentifikasi materi-materi yang diperoleh dan yang tidak diperoleh dari buku, dan

d) Menyusun program pengajaran

Sebagai langkah awal dalam mengembangkan materi adalah memilih dan menentukan topik dan judul, langkah pemilihan topik mata pelajaran mengacu pada kurikulum dan analisis instruksional, kemudian membuat peta konsep yang akan menjadi landasan ruang lingkup uraian topik mata pelajaran dalam bahan ajar bahasa Arab.

c. Penulisan dan penyusunan materi

Penyusunan, pemilihan dan penulisan bahan pembelajaran berupa buku ajar meliputi:

1) Menyusun dan menulis petunjuk

2) Menyusun dan menulis tujuan pembelajaran

3) Menyusun dan menulis uraian materi pelajaran

4) Menyusun dan menulis soal-soal, latihan-latihan, tes dan kunci jawaban,

5) Menyusun dan menulis daftar kosa kata (mufrodat)

d. Evaluasi

Pada tahap ini buku yang telah disusun dievalusi kembali. Evaluasi ini dilakukan untuk mengumpulkan data yang digunakan dalam penyempurnaan buku ajar. Untuk evaluasi bahan ajar bahasa Arab dapat dilakukan 3 langkah kajian, yaitu:

1) evaluasi tahap pertama, berupa review/kajian oleh bidang studi, dan ahli rancangan pembelajaran,

2) tahap kedua, uji coba perorangan,

3) tahap tiga, uji coba lapangan. 
e. Revisi

Proses perbaikan buku ajar tidak harus dilakukan setelah semua proses evaluasi selesai, tetapi bisa dilakukan pada setiap akhir tahap proses evaluasi, artinya tiap kali ada masukan, pada saat itu bisa diperbaiki.

\section{Penutup}

Dari uraian di atas dapat disimpulkan bahwa bahan ajar merupakan hal yang sangat penting dalam pembelajaran dan merupakan salah satu faktor yang sangat mempengaruhi berhasil atau tidaknya pembelajaran bahasa Arab di Indonesia.

Materi yang terdapat dalam bahan ajar bahasa Arab harus mencangkup empat keterampilan berbahasa yaitu: maharah al-kalam, maharah al-istima', maharah qira'ah, maharah al-kitabah dengan selalu mempertimbangkan asas-asas, karakteristik dan prinsip-prinsip yang berlaku.

Dengan kemampuan menyusun dan mengembangkan bahan ajar bahasa Arab yang berkualitas yang dimiliki oleh ahli ataupun praktisi pengajar bahasa Arab, semoga menjadi salah satu solusi dalam memecahkan masalah pembelajaran bahasa Arab di Indonesia.

\section{Bibliografi}

Abdullah Al Ghali, Nashir dan Hamid Abdullah, Abdul.Usus I'dad Al Kutub AlTa'liimiyyat li Ghairi Al Naathiqiin bihaa. Riyadh: Dar Al Gha. 1991

Abu Syairi, Khairi. "Pengembangan Bahan Ajar Bahasa Arab", Jurnal Dinamika Ilmu IAIN Samarinda, Vol. 13, No. 55

Belawati, Tian. et.al. Pengembangan Bahan Ajar.Jakarta: Pusat Penerbitan UT. 2003

B. Umo, Hamzah.Model Pembelajaran-Menciptakan Proses Belajar Mengajar yang Kreatif dan Efektif, Jakarta: Bumi Aksara. 2007

Hamid, Abdul dkk,. Pembelajaran Bahasa Arab: Pendekatan, Metode, Strategi, Materi, dan Media. Malang: UIN-Malang Press. 2008

Joni, R.T. Pengembangan Paket Belajar. Jakarta: Depdikbud. P2LPTK. 1984

Majid, Abdul. Perencanaan Pembelajaran: Mengembangkan Standar Kompetensi Guru. cet. 5. Bandung: Remaja Rosdakarya. 2008

Pannen, P. Mengajar di Perguruan Tinggi: Pengembangan Bahan Ajar. Jakarta: PAUPPAI, Universitas Terbuka. 1996 
Prastowo, Andi. Panduan Kreatif Membuat Bahan Ajar Inovatif: Menciptakan Metode Pembelajaran yang Menarik dan Menyenangkan.cet. IV. Yogjakarta: Diva Press. 2012

Syaifullah, Muhammad.Pembelajaran Kooperatif Tipe Make A Match Dalam Meningkatkan Penguasaan Kosa Kata Babasa Arab Santri TPA AlBarokah Hadimulyo Timur Metro Pusat, Jurnal At-Ta'dib, Vol 11, No.2, 2016/DOI:http://dx.doi.org/10.21111/at-tadib.v1 1i2.781.

Syaifullah, Muhammad.Pembelajaran Metode Kooperatif Tipe Jigsaw Dalam Meningkatkan Hasil Belajar Bahasa Arab (Qowa'id) Mabasiswa Perbankan Syariah LAIM NU Metro Lampung Tabun 2017, Jurnal Bahasa Lingua Scientia, Vol 9, No.2, 2017/DOI:http://doi.org/10.21274/1s.2017.9.2.177-208

Widodo, Chomsin S. dan Jasmadi.PanduanMenyusunBahanAjar Berbasis Kompetensi. Jakarta: Gramedia. 2008

Yunus, Fathi., dkk,.Ta'lim al-Lughah al-'Arabiyah. Cairo: Dar al-Nahdah. 1984 
144 | Arabiyatuna : Jurnal Bahasa Arab, Vol. 3, No. 1, 2019

HALAMAN INI SENGAJA DIKOSONGKAN 